Jurnal Kesehatan Masyarakat

\title{
THE EFFECTS OF LEAD (Pb) EXPOSURE TO BLOOD Pb CONCENTRATION AND HEMOGLOBIN LEVELS IN BOOK SELLERS AND STREET VENDORS OF SURAKARTA
}

\author{
Khotijah $^{\bowtie}$, Ipop Sjarifah, Putu Gede Oka Mahendra, Vitri Widyaningsih, Haris Setyawan \\ Occupational Safety and Health Program, Faculty of Medicine, Sebelas Maret University
}

\section{Article Info}

Article History:

Submitted April 2016

Accepted November 2017

Published November 2017

Keywords:

$\mathrm{Pb} ; \mathrm{Pb}$ blood concentration; hemoglobin levels

\section{DOI}

http://dx.doi.org/10.15294/

kemas.v13i2.5743

\begin{abstract}
Anemia is still a public health problem in the world and in Indonesia. WHO (2008) reported more than $75 \%$ of anemia in Asia is iron deficiency and $63.5 \%$ anemia in Indonesia is caused by lack of nutrition. Previous studies described that lead (Plumbum / $\mathrm{Pb}$ ) can decrease hemoglobin levels. Sriwedari markets' book sellers and Solo Wholesale Center's street vendors are susceptible populations exposed to $\mathrm{Pb}$ as a result of motor vehicle exhaust. Approximately $70 \%$ of $\mathrm{Pb}$ in vehicle exhausts emissions are emitted into the air. This study aimed to analyze the effects of $\mathrm{Pb}$ exposure on blood $\mathrm{Pb}$ concentration and hemoglobin levels. This study was a quantitative observational analytic study with cross sectional design conducted in 2015-2016 at Sriwedari Market. Samples were 97 respondents obtained through random sampling and Spearman correlation was used for data analysis. Result showed that there were association between $\mathrm{Pb}$ exposure in the air and blood $\mathrm{Pb}$ levels $(\mathrm{p}=0,000 ; \mathrm{r}=0,606)$ and blood $\mathrm{Pb}$ levels and hemoglobin levels $(\mathrm{p}=0,000 ; \mathrm{r}=-0,623)$
\end{abstract}

\section{Introduction}

The use of motorized vehicles is a major requirement for the present community. Use of motor vehicles in Indonesia is increasing from year to year and leads to the high amount of gasoline consumption (Nurbaya and Wijayanti, 2010). The use of petrol means increasing levels of Lead/Plumbum $(\mathrm{Pb})$ as a result of motor vehicle exhaust emission in the air which also increasing air pollution, with no exception in human health (Nawrot, 2006).

$\mathrm{Pb}$ is a metal that is extremely harmful to human health. $\mathrm{Pb}$ can accumulate in the body and cause acute and chronic intoxication (Ray, 2015). Acute intoxication causes hemolytic anemia, whereas chronic intoxication of $\mathrm{Pb}$ can cause hypochromic microcytic or normocytic anemia (Malekirad, 2013; Guzel, 2012). Exposure of low dose $\mathrm{Pb}$ could still causes interference on the body without showing clinical symptoms (Nawrot, 2006). Besides being very dangerous for its poisonous effect to the environment, $\mathrm{Pb}$ also has an impact on the decrease of hemoglobin $(\mathrm{Hb})$ in the blood. The high intensity of motor vehicles usage in Indonesia may increase the levels of $\mathrm{Pb}$ in the air and increase the risk for anemia due to $\mathrm{Pb}$ (Laila, 2013).

$\mathrm{Pb}$ enters the human body through a variety of ways, such as through breathing 
(inhalation), gastrointestinal, and even by dermal contact. However, an important route for human $\mathrm{Pb}$ exposure is through the respiratory tract or inhalation (Suksmerri, 2008). $\mathrm{Pb}$ that entered the body will not stay in the body completely, only approximately 5\%$10 \%$ of the amount ingested would be absorbed by the gastrointestinal tract, and approximately $5 \%$ only of the $30 \%$ that is absorbed through breathing will stay in the body. $\mathrm{Pb}$ left in the body will clump, especially in the skeleton (9095\%). To determine a person's $\mathrm{Pb}$ intoxication, analysis of $\mathrm{Pb}$ content in the blood was performed (Liu, 2015).

Book sellers of Sriwedari markets and street vendors of Solo Wholesale Center are informal sector workers or vulnerable populations to $\mathrm{Pb}$ exposure as a result of motor vehicle exhaust. For 8 hours per day and more than 5 years, these people are exposed to vehicles' $\mathrm{Pb}$ passing in the workplace. At initial observation, they often complain about dizziness and weakness, and initial examination mostly revealed below normal hemoglobin levels. This study aimed to analyze the effects of $\mathrm{Pb}$ exposure on blood $\mathrm{Pb}$ concentration and hemoglobin levels of Sriwedari Market's book sellers and Solo Wholesale Center's street vendors.

\section{Methods}

This study was a quantitative observational analytic study with cross sectional design. The population in this study is Sriwedari Market back gate booksellers and Solo Wholesale Center street vendors. Samples of 96 respondents who met the inclusion criteria were obtained through random sampling. $\mathrm{Pb}$ levels in the air and in the blood of respondents were measured using Atomic Absorption Spectrophotometry (AAS). Analysis of air $\mathrm{Pb}$ and $\mathrm{Pb}$ levels in the blood were carried out at the laboratory of Mathematics and Science, UNS, whereas hemoglobin levels test was conducted by photoelectric colorimeter instrument at Solo laboratory. Spearman correlation statistical test was used to analyze the primary data.

\section{Results and Discussion}

Based on the results of ambient air measurements for \pm 1 hour in the market area, we obtained the results of $\mathrm{Pb}$ concentration in the air, $\mathrm{Pb}$ concentration in the blood, and hemoglobin levels as shown in Table 1.

The results showed that the average concentration of $\mathrm{Pb}$ in the air was $0,041 \mu \mathrm{g} /$ $\mathrm{Nm}^{3}$ with the lowest concentration of $0.018 \mu \mathrm{g} /$ $\mathrm{Nm}^{3}$ in the book market and $0.074 \mu \mathrm{g} / \mathrm{Nm}^{3}$ is the highest levels on street vendors. According to the Government Regulation Number 41 year 1999 regarding Air Pollution Control mentioned that quality standard of $\mathrm{Pb}$ in ambient air is 2 $\mu \mathrm{g} / \mathrm{Nm}^{3}$, thus the measurement results of $\mathrm{Pb}$ concentration derived from vehicles, both on the book market and street vendors were still safe because it was below the quality standard value. Nonetheless, airborne $\mathrm{Pb}$ surveillance should be continued as the use of motorized vehicle keep increasing that $\mathrm{Pb}$ in the air may increase in the future. According to OSHA (2004), when $\mathrm{Pb}$ in the work environment air reached $40 \mu \mathrm{g} / \mathrm{m} 3$ and workers were exposed for 30 days or more, health surveillance became compulsory.

Table 1 showed the average concentration of $\mathrm{Pb}$ in the blood of respondents is $26.16 \mu \mathrm{g} / \mathrm{dL}$, which was in the normal range of $\leq 40 \mu \mathrm{g} / \mathrm{dL}$. However, the highest $\mathrm{Pb}$ blood concentration found was $57.30 \mu \mathrm{g} / \mathrm{dL}$, which already exceeded normal limits, and a total of 12 respondents (12.5\%) had a Pb content of more than $40 \mu \mathrm{g} /$ $\mathrm{dL}, 3$ of which (3.1\%) had $\mathrm{Pb}$ concentration

Table 1. Variable Tendency of Pb Concentration in Air and Blood, and Hemoglobin Levels

\begin{tabular}{llllllll}
\hline Variable & Unit & Mean & $\begin{array}{l}\text { Std. } \\
\text { Deviation }\end{array}$ & Min & Max & Range & $\begin{array}{l}\text { Normal } \\
\text { Value }\end{array}$ \\
\hline $\mathrm{Pb}$ in air & $\mu \mathrm{g} / \mathrm{Nm}^{3}$ & 0.041 & 0.028 & 0.018 & 0.074 & 0.056 & - \\
$\mathrm{Pb}$ in blood & $\mu \mathrm{g} / \mathrm{dL}$ & 26.16 & 11.69 & 0 & 57.30 & 57.30 & $\leq 40$ \\
Hemoglobin levels & $\mathrm{g} / \mathrm{dL}$ & 13.00 & 2,17 & 8.70 & 17.70 & 9.00 & - \\
a. Men & & 15.11 & 1.00 & 12.90 & 17.70 & 4.80 & $\geq 13$ \\
b. Women & & 12.09 & 1.89 & 8.70 & 17.00 & 8.30 & $\geq 12$ \\
\hline
\end{tabular}


above $50 \mu \mathrm{g} / \mathrm{dL}$.

Based on the categoryof Pbcontamination in the blood of adults, those concentration fall under acceptable category since it was still in the range of $40-80 \mu \mathrm{g} / \mathrm{dL}$. This category showed that the absorption is increased due to $\mathrm{Pb}$ pollution at abnormal levels, but still considered safe (Liu, 2015). Pb blood concentration of $>50 \mu \mathrm{g} / \mathrm{dL}$ may interfere with hemoglobin production. Therefore, the respondent with $\mathrm{Pb}$ concentration of $57.30 \mu \mathrm{g} / \mathrm{dL}$ will require continued monitoring to prevent exposure and more accumulation of $\mathrm{Pb}$ in the body that can interfere with the formation of hemoglobin. Based on the results of the measurement, respondents with $\mathrm{Pb}$ concentration above 50 $\mu \mathrm{g} / \mathrm{dL}$ required monitoring.

The average hemoglobin levels based on measurements using the photoelectric colorimeters was $13.00 \mathrm{~g} / \mathrm{dL}$ (Table 3). The average hemoglobin levels of men were 15.11 $\mathrm{g} / \mathrm{dL}$, higher than women $(12.09 \mathrm{~g} / \mathrm{dL})$. This was consistent with the theory that hemoglobin levels were higher in male than female. When analyzed based on the normal value, the average hemoglobin levels in men and women were both still in the normal level. However, the mean hemoglobin levels in women were almost at lower limit of the normal range.

Table 2 showed the results of the Kruskal-Wallis test to compare the levels of hemoglobin by $\mathrm{Pb}$ concentration category in the blood. There was a significant difference ( $p$ 0.003) where the mean hemoglobin levels for respondents with normal $\mathrm{Pb}$ levels were higher than the respondent with higher average $\mathrm{Pb}$ concentration.

According to the OSHA 1910.1025 standard of $\mathrm{Pb}$ in appendix $\mathrm{C}$, if exposure to $\mathrm{Pb}$ was low, e.g. below $40 \mu \mathrm{g} / \mathrm{dL}$ (blood), monitoring needed to be carried out every 6 months. If $\mathrm{Pb}$ in the blood of workers reached more than $40 \mu \mathrm{g} / \mathrm{dL}$, it must be monitored every two months until the level decreased below 40 $\mu \mathrm{g} / \mathrm{dL}$. If the blood $\mathrm{Pb}$ concentration reach 60 $\mu \mathrm{g} / \mathrm{dL}$ or more, OSHA required the worker to be transferred or rested with monthly surveillance and might only be working again after $\mathrm{Pb}$ blood concentration falls below $40 \mu \mathrm{g} / \mathrm{dL}$.

The results of statistical tests to examine the relationship of exposure to $\mathrm{Pb}$ in the air with $\mathrm{Pb}$ concentration in the blood and hemoglobin levels were shown in Table 1.

Before the relationship test between variables, we tested the data normality using the Kolmogorov-Smirnov and found that the data were not normally distributed because the $p$ value was $<0.05$, so we used Spearman correlation test as the statistical test method. Based on table 2, statistical analysis showed the same $p$ value in both test which was 0.000 $(p \leq 0.05)$. It means that exposure to $\mathrm{Pb}$ in the air has a significant association with $\mathrm{Pb}$ concentration in the blood and hemoglobin levels. The correlation coefficient $(r)$ is 0.606 which indicates exposure to $\mathrm{Pb}$ in the air had a strong relationship with $\mathrm{Pb}$ concentration in the blood. A positive $r$ value means the higher the exposure to $\mathrm{Pb}$ in the air, the higher the blood $\mathrm{Pb}$ concentration, and vice versa. These

Table 2. Hemoglobin Levels by $\mathrm{Pb}$ Blood Concentration Category

\begin{tabular}{llll}
\hline $\mathrm{Pb}$ blood concentration & $\mathrm{n}(\%)$ & Mean (SD)Hemoglobin & $p$ value \\
\hline$\leq 40 \mu \mathrm{g} / \mathrm{dL}$ & $84(87.5)$ & $13.24(2.15)$ & $0.003^{\star}$ \\
$40 \mu \mathrm{g} / \mathrm{dL}$ & $12(12.5)$ & $11: 31(1.50)$ & \\
Total & $96(100)$ & $13.00(2.17)$ & \\
\hline
\end{tabular}

*) $p$ value obtained through the Kruskal-Wallis test

Table 3. Relationship of $\mathrm{Pb}$ Exposure in the Air, $\mathrm{Pb}$ Concentration in Blood, and Hemoglobin Levels

\begin{tabular}{llll}
\hline No. & Variable & Significance $(\mathrm{p})$ & $\begin{array}{l}\text { Correlation Coefficient } \\
(\mathrm{r})\end{array}$ \\
\hline 1. & $\mathrm{Pb}$ in the air with $\mathrm{Pb}$ in blood & $<0.001$ & 0.606 \\
2. & $\mathrm{Pb}$ in the air with Hemoglobin levels & $<0.001$ & -0.623 \\
\hline
\end{tabular}


results were consistent with study by Mardani, (2005) on Traffic Service and Road Transport Officer of Surakarta that $\mathrm{Pb}$ concentration in ambient air had a positive correlation with $\mathrm{Pb}$ concentrantion in blood. In addition, according to a study by Muliyadi, (2015) there was a correlation between $\mathrm{Pb}$ concentration in air with $\mathrm{Pb}$ concentration in blood of car painting workers with $\beta=0.667$ and $p<0.001$.

In the next variable, the correlation coefficient was 0.623 and it indicated that exposure to $\mathrm{Pb}$ in the air have a strong relationship with hemoglobin levels. However, a negative $r$ indicate opposite correlation between the two variables which means the higher exposure to $\mathrm{Pb}$ in the air, the lower the hemoglobin levels, and vice versa.

This study showed that respondents who have higher concentration of $\mathrm{Pb}$ in blood, have a lower hemoglobin levels. Previous studies also suggest a link between $\mathrm{Pb}$ with hemoglobin levels in workers exposed to $\mathrm{Pb}$ (Qasim \& Baloch 2014; Sadeghi, 2014; Malekirad, 2013). A study by Richard, (2006) showed that exposure to $\mathrm{Pb}$ could inhibit heme biosynthesis via coproporphyrinogen enzyme, $\delta$-ALAD and ferrochelatase inhibition. Inhibition of these enzymes caused a decrease in hemoglobin levels in the blood (Ray, 2015). Preventive measures should be taken for workers exposed to $\mathrm{Pb}$ in order to avoid hazards caused by $\mathrm{Pb}$ intoxication. Primary prevention can be done by avoiding $\mathrm{Pb}$ exposure or keeping $\mathrm{Pb}$ concentration in air below the threshold value (Flora, 2012; Koh, 2015). In addition, environmental monitoring to measure $\mathrm{Pb}$ concentration in the environment and biomonitoring to measure the levels of $\mathrm{Pb}$ in the body were important for workers at risk of exposure to $\mathrm{Pb}$ (Flora, 2012).

\section{Conclusion}

Exposure to $\mathrm{Pb}$ in air had a significant correlation with $\mathrm{Pb}$ concentration in blood and hemoglobin levels. The higher the concentration of $\mathrm{Pb}$ in air, the higher the $\mathrm{Pb}$ concentration in blood, and the lesser the hemoglobin levels. Book seller of Sriwedari market was a vulnerable population, and therefore needed appropriate regulation. Regulatory steps could include administration control (adjust the length of working outside the work space that allowed exposure to $\mathrm{Pb}$ ), use of personal protective equipment (wearing mask to protect from $\mathrm{Pb}$ exposure), and getting used to conduct a safe and healthy habit (getting used to the implementation of working hours arrangement in the working place and implemented a disciplined use of masks as well as adequate consumption of nutritious foods and water). The safety and health of informal workers were the responsibility of both the workers themselves and the agency in charge of occupational health in the informal sector such as community health centers. Therefore, the community health center should also be involved in health education of informal sector workers.

\section{References}

Flora, G., Gupta, D. \& Tiwari, A. 2012. Toxicity of Lead: a Review with Recent Updates. Interdisciplinary Toxicology, 5 (2) : 47-58

Guzel, S. et al. 2012. Association of $\mathrm{Pb}, \mathrm{Cd}$, and Se Concentrations and Oxidative DamageRelated Markers in Different Grades of Prostate Carcinoma. Biological Trace Element Research, 145 (1) : 23-32

Koh, D.H. et al. 2015. Lead Exposure in US Worksites: A Literature Review and Development of an Occupational Lead Exposure Database from the Published Literature. American Journal of Industrial Medicine, 58 (6) : 605-616.

Laila, Nur Najmi., Shofwati, I. 2013. Kadar Timbal Darah dan Keluhan Kesehatan pada Operator Wanita SPBU. Jurnal Kesehatan Reproduksi, $4(1): 41-49$

Liu, C. et al. 2015. Association between Blood Erythrocyte Lead Concentrations and Hemoglobin Levels in Preschool Children. Environmental Science and Pollution Research, 22 (12) : 9233-9240.

Malekirad, A.A., Kalantari-Dehaghi, R. \& Abdollahi, M. 2013. Clinical, Haematological, and Neurocognitive Findings in Lead-Exposed Workers of a Battery Plant in Iran. Archives of Industrial Hygiene and Toxicology, 64 (4) : 497-503

Mardani, T.R., Setiyono, P. \& Listyawati, S. 2005. Kadar Timbal $(\mathrm{Pb})$ dalam Darah dan Hubungannya dengan Kadar $\mathrm{Hb}$ Darah Akibat Emisi Kendaraan Bermotor pada Petugas DLLAJ di Kota Surakarta. BioSMART, 7 (1) : 60-65.

Muliyadi, Mukono, H.J. \& Notopuro, H. 2015. Paparan Timbal Udara Terhadap Timbal Darah, Hemoglobin, Cystatin C Serum Pekerja Pengecatan Mobil. Jurnal Kesehatan 
Masyarakat, 11 (1) : 87-95.

Nawrot, T.S. \& Staessen, J.A. 2006. Low-level Environmental Exposure to Lead Unmasked as Silent Killer. Circulation, 114 (13) : 13471349.

Nurbaya, F., Wijayanti, Y. 2010. Faktor Risiko yang Berhubungan dengan Kadar Timah Hitam Dalam Darah. Jurnal Kesehatan Masyarakat, $6(1): 51-56$.

OSHA. 2004. Lead and Health Topics Construction, US: Department of Labor.

Qasim, S.F. \& Baloch, M., 2014. Lead Toxicity in Battery Workers. Journal of the College of Physicians and Surgeons Pakistan, 24 : S284S286.

Ray, R.R. 2015. Haemotoxic Effect of Lead: A Review. Proceedings of the Zoological Society.

Richard, S.A.; Phillips, JD.; Kushner, J. 2006.
Biosynthesis of Heme in Mammals. Biochemistry and Biophysics Actual, 17(63) : 723-736.

Sadeghi, H.R. et al. 2014. The Relationship between Blood Lead Level with Iron Status and Hemopoietic Parameters in Smoker and Non-Smoker Workers at Lead Battery Factory. Comparative Clinical Pathology, 24(5) : 1111-1115.

Suksmerri, 2008. Dampak Pencemaran Logam Timah Hitam $(\mathrm{Pb})$ terhadap Kesehatan. Kesehatan Masyarakat, 2 (2).

World Health Organization. 2008. World Health Statistics, Geneva: The United Nation Environment Programme, The International Labour Organization and World Health Organization. 